Ewa Kozik

Uniwersytet Śląski

(D) https://orcid.org/oooo-0003-1129-0536

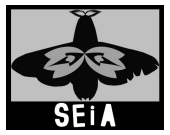

\title{
Jak troszczyć się o życie? Antyszczepionkowe narracje spiskowe w czasie pandemii COVID-19*
}

How best to protect life? Anti-vaccine conspiracy narratives during the COVID-19 pandemic

Summary: The aim of this article is to discuss the social attitudes adopted by representatives of the anti-vaccine movement in response to the threat posed by the COVID-19 pandemic. A critical analysis of this discourse, represented by texts in the virtual space, identifies the distinctive features of the anti-vaccination narratives that developed in response to information on the need to develop and roll out vaccine to combat COVID-19. The analysis focuses primarily on texts posted on the alternative news portal Free Media. Ewa Kozik has taken into account the most popular conspiracy theories, which directly relate to the worldview of the opponents of vaccination.

Keywords: pandemic, COVID-19, magical thinking, conspiracy narratives, vaccines Słowa kluczowe: pandemia, COVID-19, myślenie magiczne, narracje spiskowe, szczepionki

\section{Narracje antyszczepionkowe a pandemia COVID-19}

Przeciwnicy szczepień, popularnie nazywani antyszczepionkowcami, tworzą dziś jedną z najbardziej znanych grup o charakterze aktywistycznym, która za pomocą nowych mediów manifestuje swój sprzeciw wobec obowiązkowi szczepień bądź też wobec szczepieniom jako takim. Celem antyszczepionkowców staje się informowanie społeczeństw o ryzyku, jakie pociąga za sobą stosowanie szczepionek, a także prowadzenie walki z rzekomym systemem narzucającym ludziom jedyny typ profilaktyki chorób, jakim jest szczepienie. Dominującą aktywnością antyszczepionkowców jest publikowanie w cyberprzestrzeni treści objaśniających utajony sposób działania szczepionek, mających powodować liczne choroby, na przykład autyzm ${ }^{1}$.

* Źródło finansowania badań przedstawionych w artykule: badania własne.

1 A. Demczuк: Fenomen ruchu antyszczepionkowego w cyberprzestrzeni..., czyli fake news i postprawda na ustugach hipotezy Andrew Wakefielda. „Annales Universitatis Paedagogicae Cracoviensis. Studia de Cultura" 2018, [t.] 10 (4), s. 92-97. 
Niniejszy artykuł zawiera analizę polskich narracji antyszczepionkowych, replikujących się w przestrzeni wirtualnej $\mathrm{w}$ trakcie trwania pandemii COVID-19 w 2020 i 2021 roku. Nawet jeśli poddawane analizie teksty zbierano od marca do sierpnia pierwszego roku trwania pandemii, są one reprezentatywne dla całego wyszczególnionego okresu. Nieznany wcześniej wirus pochodzenia odzwierzęcego o dużej zaraźliwości, $\mathrm{z}$ gatunku koronawirusów - SARS-CoV-2, wywołał konieczność izolacji społecznej, zmiany planów i trybu życia szerokich rzesz ludności w celu ochrony zdrowia. Środki podjęte $\mathrm{w}$ walce $\mathrm{z}$ pandemią spowodowały kryzys gospodarczy, a nawet medyczny. Świat i styl życia na Zachodzie zmieniły się wówczas diametralnie, a zniecierpliwieni lub przerażeni ludzie zaczęli głośno pytać: kiedy to się skończy? Światowa Organizacja Zdrowia, prezydenci państw i ministrowie zdrowia niemal jednogłośne odpowiadali, że pandemia może zostać ostatecznie zażegnana jedynie wtedy, gdy zostanie wynaleziona, przetestowana i zastosowana szczepionka zawierająca nieaktywny materiał genetyczny SARS-CoV-2. Krytyczna analiza dyskursu antyszczepionkowego, który powstał w odpowiedzi na medialne doniesienia o konieczności opracowania i masowego zastosowania szczepionki przeciw COVID-19, posłużyła w artykule za środek pozwalający znaleźć odpowiedź na pytanie: w jaki sposób przeciwnikom szczepionek udało się okiełznać doniesienia oficjalnych mediów o SARS-CoV-2 i o sposobach jego zwalczania, w jaki sposób udało się te informacje opanować, wpisać je we własne narracje antyszczepionkowe, jeśli zauważyć, że oficjalne doniesienia uderzały w trzon światopoglądu, według którego szczepionki są szkodliwe lub zbędne w ochronie zdrowia? Mówiąc najprościej: jakimi zabiegami konceptualizacyjnymi musieli posłużyć się nadawcy reprezentujący ruchy antyszczepionkowe, żeby doniesienia medialne o walce $\mathrm{z}$ wirusem mogły uprawomocniać ich obraz świata, a nie go podważać czy mu wręcz zaprzeczać.

Celem w artykule jest prześledzenie niektórych narracji antyszczepionkowych, reprodukujących się $\mathrm{w}$ cyberprzestrzeni $\mathrm{w}$ pierwszych miesiącach trwania pandemii COVID-19, od marca do sierpnia 2020 roku, pod względem obecnych w nich elementów myślenia magicznego, które - jak zamierzam udowodnić - stanowi implicytną sensotwórczą matrycę dyskursu antyszczepionkowego. Można w tym trybie określić, $\mathrm{w}$ jaki sposób współczesny cyfrowy tubylca, który utożsamia się z ruchami antyszczepionkowymi, radzi sobie z poczuciem zagrożenia, a jednocześnie chroni własny światopogląd przed możliwością jego podważenia. Przynależność do ruchu antyszczepionkowego lub podatność na działanie teorii spiskowych traktuję jako swoisty sposób bycia w świecie, jaki ukonstytuował się jako odpowiedź na różnorakie potrzeby, z których najistotniejsze są: potrzeba bezpieczeństwa, kontroli nad własnym życiem oraz poczucia sprawczości w zakresie własnego dobrostanu, przede wszystkim zaś zdrowia. 
Krzysztof Dołowy w książce Wbrew bogom, czyli od magii i religii do metody naukowej... i z powrotem ${ }^{2}$ wspomina o ewolucyjnych podstawach tendencji do ignorowania faktów niezgodnych $\mathrm{z}$ własnymi przekonaniami. Autor wskazuje na fakt, że ludzka skłonność do wiązania przypadkowych zjawisk w ciągi przyczynowo-skutkowe ma ewolucyjny rodowód. Opierające się na takim przywiązaniu myślenie odznacza się przekonaniem o nieuchronnych następstwach wszelkich zdarzeń. Skoro wszystko przynosi jakiś skutek, najlepszym sposobem na opanowanie mało zrozumiałych zjawisk jest ustalenie ich domniemanych przyczyn. Jeśli dowolne trudno uchwytne zjawisko stanowi skutek jakiegoś wcześniejszego stanu rzeczy, łatwo nad tym zjawiskiem poznawczo zapanować w trybie bezzwłocznego zidentyfikowania jego przyczyn. Słowem: jeśli jednoznacznie wskazana przyczyna ma równie jednoznaczny skutek, zrozumienie jakiegokolwiek zjawiska możliwe jest przez poznawcze uchwycenie tego, co do niego doprowadziło. To tylko jeden z przejawów mechanizmu wypracowanego na drodze ewolucji, który każe człowiekowi podążać za tym, co jawi mu się jako pewne, sprawdzone, a tym samym niezawodne ${ }^{3}$.

Innym przejawem podobnego mechanizmu jest tendencja do trwania przy wypróbowanym sposobie porządkowania zjawisk, nawet jeśli poszczególne fakty kwestionują jego zasadność. W odniesieniu do trwałości potocznej wizji świata polski folklorysta Piotr Kowalski pisze: „Zanim jednak zmieni się kulturowy paradygmat, długo, gwałtownie

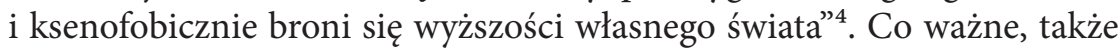
zjawiska, które skądinąd wymykają się uznawanemu porządkowi rzeczy, mogą taki porządek potwierdzać. Nigdy bowiem nie są "nagimi faktami”, zawsze stanowią wynik określonej interpretacji, która jest zazwyczaj niejawna. Wystarczy zatem odczytać fakty w taki sposób, by uprawomocniały aktualną w danym czasie wizję świata, a nie ją podważały ${ }^{5}$. To samo dotyczy powszechnie obowiązującej w określonym środowisku teorii, która zapewnia ludziom poczucie bezpieczeństwa. Większe zagrożenie pociąga za sobą ewentualność jej obalenia aniżeli konieczność naginania do niej konkretnych spostrzeżeń lub ignorowania ich, jeśli jej przeczą.

Nagłość spraw, z którymi musieli się mierzyć nasi przodkowie, przekłada się na tendencję do skrótowego myślenia, której wyrazem jest myślenie magiczne. Nie dotyczy ono wyłącznie społeczeństw przed-

2 K. DoŁowy: Wbrew bogom, czyli od magii i religii do metody naukowej... i z powrotem. Warszawa 2020.

3 Ibidem, s. 452-454.

4 P. Kowalski: Theatrum świata wszystkiego i poćciwy gospodarz. O wizji świata pewnego siedemnastowiecznego pisarza ziemiańskiego. Kraków 2000, s. 37.

5 Ibidem, s. 39. 
industrialnych, jak uważali niektórzy klasycy antropologii ${ }^{6}$. Jan Kajfosz pisze w kontekście tego typu myślenia o logice typu skojarzeniowego, o myśleniu typu syntetycznego, które dominuje na poziomie spontanicznych doznań - w ramach postaw przedrefleksyjnych. Narracje wynikające $z$ danego typu myślenia pozwalają się odczytać jako rezultat spontanicznej kategoryzacji w tym znaczeniu, że zawierają zawsze klarowną, łatwo przyswajalną wiedzę, absolutną $\mathrm{w}$ tym sensie, że umożliwia ona doskonałe rozumienie każdej sytuacji życiowej, nie budząc najmniejszych wątpliwości - nie wymagając weryfikacji ani też jakichkolwiek dopowiedzeń ${ }^{7}$. Podobna wiedza odznacza się naocznością, stanowi efekt tendencji do skrótu w żywiołowym, spontanicznym sposobie rozumienia rzeczy. Jakakolwiek przypadkowa współobecność zjawisk może tu zostać odebrana jako ich zależność, zwłaszcza że myślenie magiczne nie zna ani kategorii przypadku, ani rachunku prawdopodobieństwa. Funkcjonowanie na gruncie potoczności wymaga szybkich konkluzji i decyzji. Epistemologiczne rewizje, które odwracałyby uwagę człowieka od naocznych spraw, byłyby na planie potocznej percepcji świata nie tylko bezużyteczne, ale wręcz kontrproduktywne ${ }^{8}$.

Żadna z ostrożnych hipotez czy teorii naukowych nie może zaspokoić potrzeby natychmiastowego zrozumienia, dlaczego wirus rozprzestrzenia się niezwykle szybko. Żadna nie może dać rychłego wytłumaczenia tego, w jaki sposób powstała choroba COVID-19. Za sprawą myślenia magicznego jednak to, co zmienne, nieczytelne, co najmniej częściowo arbitralne i różnorodne, przekształca się w to, co proste, łatwo zrozumiałe i wszechobecne. W ten sposób rodzi się pomyślany, a w konsekwencji także doświadczany kosmos, w którym nie ma miejsca na wątpliwości, bo rządzą nim prawa dające się łatwo i bezzwłocznie odczytać. Nie tylko dla myślenia magicznego, lecz w ogóle dla sensualistycznego sposobu percepcji świata charakterystyczny jest „mechanizm brania reprezentacji za samą rzeczywistość"'. Brak rozróżnienia pomiędzy znakiem a jego przedmiotem może skutkować między innymi tym, że doniesienie o wydarzeniu i samo wydarzenie zleją się w jedno doświadczane zjawisko ${ }^{10}$. W efekcie słowo i obraz, zamiast reprezentować rzeczywistość, tworzą ją. Za przykład niech posłuży zauważone przez Jeana Baudrillarda utożsa-

6 L. LÉvy-BRuHL: Czynności umysłowe w społeczeństwach pierwotnych. [Przeł. B. SzWarcman-Czarnota]. Warszawa 1992.

7 J. KajFosz: Dyskurs analityczny i syntetyczny, czyli myślenie magiczne w perspektywie antropologii kognitywnej. „Artes Humanae” 2016, vol. 1, s. 27-42.

8 P.L. Berger, T. Luckmann: Społeczne tworzenie rzeczywistości. Traktat z socjologii wiedzy. Przeł. J. NiżNıк. Warszawa 2010, s. 24-35.

9 C. Rовотүскі: Społeczność a wspótczesny regionalizm i tożsamość lokalna. „Zeszyty Etnologii Wrocławskiej” 2012, [nr] 2 (17), s. 31.

10 J. ToKarsKa-Bakir: Obraz osobliwy. Hermeneutyczna analiza źródeł etnograficznych. Kraków 2000, s. 39-40. 
mienie niegdysiejszej wojny w Zatoce Perskiej z jej medialnym obrazem wykreowanym przez stację telewizyjną CNN, do czego odnosiło się głośne swego czasu stwierdzenie, że „wojny w Zatoce nie było" ${ }^{11}$.

Jeśliby wrócić do interesującego nas dyskursu antyszczepionkowego, można stwierdzić, że gdyby przeciwnicy szczepień zgodzili się na tezę, iż najlepszy sposób na pokonanie koronawirusowego zagrożenia stanowi szczepionka, częściowo lub całkowicie zaprzeczyliby głoszonym przez siebie dotychczas poglądom. Chaos informacyjny oraz niejednoznaczność rządowych zaleceń walki z pandemią stworzyły jednak dla nich możliwość takiego ustosunkowania się do szczepień przeciw COVID-19, by nie zaprzeczali własnym dotychczasowym narracjom. Ze względu na ukształtowaną przez ewolucję dyspozycję do unikania kognitywnych dysonansów byłoby to zresztą niebezpieczne.

Przestrzeń internetowa jest bogatym polem badawczym dla antropologa kulturowego, jednak ze względu na różnorodność tej przestrzeni jej eksploracja wymaga szczególnej wrażliwości. Już tylko sam dobór treści przeznaczonych do analizy łatwo może stać się powodem podejrzeń o tendencyjną wybiórczość. Dlatego, kierując się zasadą, że nie ma tekstu bez kontekstu, koncentruję się $\mathrm{w}$ artykule niemal całkowicie na narracjach antyszczepionkowych, które powstały w odpowiedzi na doniesienia mediów publicznych oraz społecznościowych na temat pandemii COVID-19, pojawiające się w pierwszych miesiącach trwania pandemii, czyli od stycznia do czerwca 2020 roku. Na potrzeby niniejszego artykułu zawężyłam teren wirtualnych eksploracji do samych tylko artykułów upublicznianych w serwisie internetowym Wolne Media ${ }^{12}$, cieszących się względnym rezonansem społecznym. Oprócz tego poddałam analizie zasłyszane narracje, na jakie natknęłam się w trakcie bezpośredniego kontaktu z informatorami reprezentującymi środowiska antyszczepionkowe.

$\mathrm{Na}$ portalu Wolne Media ${ }^{13}$ każdy może opublikować artykuły lub filmy, pod warunkiem, że zostaną one zaakceptowane przez administratora. $\mathrm{W}$ poradniku dla autorów dodatkowo znajduje się zalecenie, aby dołożyli oni wszelkich starań, by ich artykuły były jak najbardziej obiektywne, i aby unikali stosowania wartościujących określeń. Ze względu na sposób działania tej witryny traktuję ją jako przykład opozycyjnej alternatywy dla głównego nurtu informacyjnego mediów publicznych.

Chcąc uchwycić nowo powstałe narracje antyszczepionkowe powstałe w odpowiedzi na pandemię COVID-19, posłużyłam się krytyczną analizą dyskursu, wypracowaną przez Normana Fairclougha w książce Language and power $^{14} \mathrm{z} 1989$ roku, a kontynuowaną później między in-

11 J. Baudrillard: Wojny w Zatoce nie było. Przeł. A. Królak. Warszawa 2006.

12 Wolne Media. https://wolnemedia.net/ [data dostępu: 30.04.2020].

13 O nas. Wolne Media. https://wolnemedia.net/o-nas/ [data dostępu: 30.04.2020].

14 N. FairClough: Language and power. London 1989. 
nymi przez Teuna A. van Dijka oraz Ruth Wodak ${ }^{15}$. Fairclough interesował się tym, w jaki sposób władza polityczna realizuje się za pomocą mechanizmów językowych oraz w jakim stopniu reklama, promocja oraz media uzależnione są od reguł działania języka i dyskursu. Tekst - jako przedmiot badań - jest tu rozumiany szeroko, multimodalnie, a więc nie tylko jako wypowiadane lub zapisywane słowa, lecz również jako współdziałające z nimi obrazy. Podobne podejście do dyskursu zakłada, że jest on swoistym organizatorem życia społecznego. Oznacza to, że określa sposoby konstruowania społecznie podzielanych znaczeń i społecznie uznawanych tożsamości, określa tak samo formułowane poglądy i podejmowane działania. Pod tym względem dyskurs współtworzy zarówno sposoby bycia w świecie, jak i sposoby łączenia różnorodnych reprezentacji bytu $\mathrm{w}$ jeden świat ${ }^{16}$. Konstatacja ta okazuje się ważna zwłaszcza $\mathrm{w}$ świetle tego, że narracje przeciwników szczepionek splatają się z teoriami spiskowymi. Podobne teorie uzyskują wymiar społeczny wówczas, gdy ich warianty reprodukują się wśród członków jakiejś społeczności komunikacyjnej, w określonym środowisku. W ramach dyskursu antyszczepionkowego funkcjonują narracje spiskowe, które między innymi zaprzeczają łatwo sprawdzalnym faktom, a najczęściej także wypracowanym przez naukę i uznawanym przez nią konsensusom.

W odniesieniu do etycznych kwestii podejmowanej tu analizy należy podkreślić, że wszelkie fragmenty niniejszego artykułu, które mogłyby zostać przez czytelnika potraktowane jako próba podważenia lub zdekonstruowania światopoglądu dyspozytorów dyskursu antyszczepionkowego, są jedynie naukowym omówieniem jednego $\mathrm{z}$ wielu rodzajów narracji niosących znamiona myślenia magicznego. Pod tym kątem będą też one rozpatrywane, przy czym celem proponowanej tu analizy nie jest kwestionowanie słuszności czyjegoś stanowiska, a jedynie opis swoistych mechanizmów konstruujących dyskurs w odniesieniu do zastanego kontekstu. Słowem: celem jest odpowiedź na pytanie, w jaki sposób uczestnicy dyskursu antyszczepionkowego konceptualizują świat, a nie na pytanie, jaki jest świat w swej istocie.

15 N.L. Fairclough, R. Wodak: Critical discourse analysis. W: Discourse studies. A multidisciplinary introduction. Vol. 2: Discourse as social interaction. Ed. T.A. VAN DiJK. 1997, s. 258-284.

16 A. Malewska-SzaŁYgin: Tradycja stosowania pojęcia dyskurs i jego przydatność $w$ antropologii współczesności. „Etnografia Polska” 2004, t. 48, z. 1-2, s. 82-83. 


\section{Wbrew naszej woli}

Pierwsze postawy antyszczepionkowe wywołała wariolacja dokonana w XVIII wieku przez Zabdiela Boylstona i Cottona Mathera, czyli uodparnianie przez zakażenie wirusem ospy prawdziwej ${ }^{17}$. Eskalacja podobnych postaw nastąpiła w połowie XIX wieku, kiedy obowiązek szczepienia przeciwko ospie prawdziwej $\mathrm{w}$ niektórych środowiskach potraktowano jako zamach na wolność i pogwałcenie praw obywatelskich ${ }^{18}$. Współcześni antyszczepionkowcy to najczęściej ludzie związani z proekologicznymi ugrupowaniami, a także zwolennicy szeroko rozumianej medycyny naturalnej lub holistycznej ${ }^{19}$. Wyniki obserwacji treści występujących w cyberprzestrzeni świadczą o tym, że przywołany wcześniej zarzut dotyczący prewencji ospy jest wciąż żywy i aktualny. Przeciwnicy szczepień do swoich narracji włączają elementy nawiązujące do polityki i oceny decyzji władz. Antyszczepionkowe narracje nabierają charakteru wezwań do walki z systemem, odwołują się do dobra wspólnego obywateli, przeciwko którym rzekomo działają rządy lub bliżej nieokreślone elity. Podobne argumentacje przybierają nieraz kształt teorii spiskowych. Narracje spiskowe tym się odznaczają, że prezentują się jako ujawnienia informacji, które dotyczą spraw publicznych, a które pozostawały utajone wskutek nacisków pewnych grup, mających na celu przejęcie władzy lub kontroli nad innymi ${ }^{20}$. Najczęściej elementy spiskowe w narracji antyszczepionkowej dotyczą planów wprowadzenia "nowego porządku świata” i związanej z nim konieczności depopulacji świata za pomocą szczepionek.

Wielu umiarkowanych antyszczepionkowców, deklarujących akceptację niektórych szczepionek (np. przeciw gruźlicy), swoje negatywne stanowisko wobec przymusowych szczepień uzasadnia brakiem przyzwolenia na odbieranie ludziom wolności decydowania o własnym zdrowiu. Przedstawiciele tej grupy uważają, że współcześnie szczepienia są przymusowe $\mathrm{w}$ wypadku zbyt wielu chorób, a niektóre szczepionki, na przykład przeciw grypie, nie mają racji bytu, ponieważ wirus powodujący tę chorobę mutuje $\mathrm{w}$ tak szybkim tempie, że szczepionka nie może dawać gwarancji odporności. Jak wynika $\mathrm{z}$ dyskusji internetowych (między innymi na portalu Wolne Media i wRealu2 ${ }^{21}$ ), każda nieudana próba zwalczenia choroby za pomocą szczepionki staje się argumentem eksploatowanym przez środowiska antyszczepionkowców na wiele spo-

17 A.K. Marchewka, A. Majewska, G. MŁynarczyk: Działalność ruchu antyszczepionkowego, rola środków masowego komunikowania oraz wpływ pogląów religijnych na postawę wobec szczepień ochronnych. „Postępy Mikrobiologii” 2015, t. 54, z. 2, s. 95-96.

18 Ibidem, s. 96.

19 Ibidem, s. 95.

20 F. Czech: Spiskowe narracje i metanarracje. Kraków 2015, s. 13.

21 Wolne Media. https://www.wolnemedia.net [data dostępu: 15.05.2020]; wRealu24. https://www.wrealu24.pl [data dostępu: 15.05.2020]. 
sobów. W swoich narracjach internauci-antyszczepionkowcy powołują się na przykłady nieskutecznego lub szkodliwego dla zdrowia użycia szczepionek. Przykłady te są dobierane, interpretowane i uprawomocniane $\mathrm{w}$ taki sposób, by powstawało wrażenie, że opinie specjalistów $\mathrm{w}$ dziedzinie epidemiologii oraz twórców szczepionek podważane są przez innych specjalistów o tej samej randze, stażu pracy czy dorobku naukowym ${ }^{22}$. Brak kryteriów pozwalających na segregację i selekcję sprzecznych narracji, z których żadna nie ma uprzywilejowanej pozycji, to jedna $\mathrm{z}$ konsekwencji nowoczesności ${ }^{23}$. To jednocześnie cecha charakterystyczna dla epoki postprawdy, którą można rozumieć jako formację wiedzy powstałą $\mathrm{w}$ związku $\mathrm{z}$ upadkiem konsensualnych i długotrwałych autorytetów, zwłaszcza naukowych. Słowo „postprawda” odnosi się zatem nie do samych informacji, lecz do specyficznych warunków ich przekazywania, w których różnice pomiędzy tym, co prawdziwe, a tym, co nieprawdziwe, stają się niesprawdzalne - albo też w ogóle tracą jakiekolwiek znaczenie - na korzyść retorycznej skuteczności przekazu ${ }^{24}$.

Zdaniem internautów-antyszczepionkowców nakładany na obywateli obowiązek szczepień jest krokiem ku odebraniu im wolności, a taki przymus należy traktować $w$ kategoriach zamachu na jednostkową niezależność oraz podważania uprawnienia i zdolności każdej jednostki do decydowania o sobie i własnym zdrowiu. Słowa takie jak „przymus", „obowiązek”, „nakaz” w antyszczepionkowych narracjach odnoszą się do przeciwdziałania chorobom zakaźnym, które opiera się na grze jawnych i niejawnych postaci przemocy ${ }^{25}$. Wyrażenia te użyte $\mathrm{w}$ kontekście ochrony własnego zdrowia nie są neutralne, posiadają emocjonalny wydźwięk, budząc czujność i niepokój odbiorców, czego dowodem jest liczba artykułów, których autorzy operują podobnymi kategoriami, zamieszczonych w serwisie Wolne Media. Już same nagłówki publikowanych tam treści wskazują na poczucie zagrożenia oraz wolę oporu: Państwo namawia na szczepionki przeciw grypie ${ }^{26}$; Trwa medialna nagonka, by wstrzykiwać szczepionki $M M R^{27}$; Badaja, jak przekonać ludzi do szcze-

22 Czy istnieja jakieś bezpieczne szczepionki? Wolne Media, 6.01.2020. https://wolne media.net/czy-istnieja-jakies-bezpieczne-szczepionki/ [data dostępu: 15.05.2020].

23 A. Giddens: Konsekwencje nowoczesności. Przeł. E. Kleкот. Kraków 2000, s. 3-5.

24 J. Kajfosz: Neoliberalism, the rise of new media folklore and the emergence of new nationalisms. „Berlin Journal of Critical Theory” 2019, vol. 3, no. 2, s. 29-31.

25 Patrz np. materiał wideo Przymusowe szczepionki od Billa Gatesa. Wolne Media, 25.05.2020. https://wolnemedia.net/przymusowe-szczepionki-od-billa-gatesa/ [data dostępu: 17.08 .2020$]$.

26 Państwo namawia na szczepionki przeciw grypie. Wolne Media, 26.09.2018. https://wolnemedia.net/panstwo-namawia-na-szczepionki-przeciw-grypie/ [data dostępu: 17.08 .2020$]$.

27 Trwa medialna nagonka, aby wstrzykiwać szczepionki MMR. Wolne Media, 6.11.2020. https://wolnemedia.net/trwa-medialna-nagonka-aby-wstrzykiwac-szczepion ki-mmr/ [data dostępu: 17.08.2020]. 
pień na COVID- $19^{28}$. Podobna retoryka sprawia, że obowiązek szczepień staje się swoistym synonimem odebrania wolności obywatelom.

$\mathrm{Na}$ dyskurs antyszczepionkowy składa się między innymi argumentacja, że skoro osoba $\mathrm{z}$ nowotworem może dobrowolnie zrezygnować $\mathrm{z}$ radio- lub chemioterapii, tak samo każdy obywatel powinien mieć prawo do rezygnacji ze szczepień ${ }^{29}$. W narracji nie wybrzmiewa jednak zasadnicza różnica pomiędzy nowotworem a chorobą zakaźną. Kto rezygnuje z terapii, ryzykuje utratę własnego zdrowia lub życia. Brak obowiązkowych szczepień oznacza natomiast, że ryzyko nie dotyczy tylko jednej osoby, lecz całej populacji.

Ilość materiałów dotyczących szczepionek, jakie zaczęły pojawiać się w sieci po wybuchu pandemii, może świadczyć o tym, że opinia publiczna na nowo zainteresowała się rolą szczepień w walce z chorobami wirusowymi ${ }^{30}$. Gdy tylko media zaczęły podawać informacje o zaawansowaniu prac nad szczepionką przeciw COVID-19, a ówczesny minister zdrowia, Łukasz Szumowski, potwierdził, że do normalnego trybu życia przyjdzie nam powrócić dopiero wtedy, gdy szczepionka zostanie wyprodukowana, przetestowana i w końcu zastosowana, przeciwnicy szczepień poczuli się uderzeni w swój najczulszy punkt. Słowa polityków i medyków wywołały wśród nich wyraźny niepokój. Wielu współtwórców dyskursu antyszczepionkowego założyło, że szczepienie przeciwko COVID-19 będzie obowiązkowe, co świadczy poniekąd o tym, jak wielkie obawy panowały w danym środowisku przed możliwym ustawowym przymusem, mimo że żaden polityk nie wspomniał o ewentualności takiego obowiązku.

Podczas dyskusji na temat oporu antyszczepionkowców wobec szczepień przeciw COVID-19 jedna ze zwolenniczek tego ruchu zwróciła uwagę na zagrożenie, jakie niesie stosowanie jakiegokolwiek specyfiku, którego skutki uboczne nie zostałyby opisane na podstawie obserwacji trwających przez dziesięciolecia. W komentarzach pod krótkim artykułem Rafała Chałasińskiego dotyczącym aktywności przeciwników szczepień domagała się wyników rzetelnie przeprowadzonych badań

28 Badaja, jak przekonać ludzi do szczepień na COVID-19. Wolne Media, 4.08.2020. https://wolnemedia.net/badaja-jak-przekonac-ludzi-do-szczepien-na-covid-19/ [data dostępu: 17.08 .2020$]$.

$29 \mathrm{Na}$ podstawie rozmowy $\mathrm{z}$ przedstawicielem ruchu antyszczepionkowego przeprowadzonej 6 czerwca 2020.

30 Zob. np.: Wiara $w$ szczepionki to absurd. Chlorochina rokuje nadzieje. Wolne Media, 15.05.2020. https://wolnemedia.net/wiara-w-szczepionki-to-absurd-chlorochinarokuje-nadzieje/ [data dostępu: 29.08.2020]; Naukowcy ONZ przyznali, że szczepionki zabijaja ludzi. Wolne Media, 12.01.2020. https://wolnemedia.net/naukowcy-onzprzyznali-ze-szczepionki-zabijaja-ludzi/ [data dostępu: 29.08.2020]; Szczepionki albo $\dot{z} y c i e$. Wolne Media, 18.08.2020. https://wolnemedia.net/szczepionki-albo-zycie/ [data dostępu: 28.08.2020]. 
nad szczepionką. Deklarowała również, że nigdy nie pozwoli podać sobie szczepionki w ramach przedsięwzięcia, które należy traktować jako eksperyment. Można przypuszczać, że internautką kierował niepokój o własne życie i zdrowie, a jej argumenty były strategią obronną. Kobieta powoływała się na wolność obywatelską, wskazywała potrzebę naukowych dowodów na bezpieczeństwo stosowania szczepionki. Chciała zobaczyć wyniki „badan’”, czekała na rezultaty „testu” przeprowadzonego „eksperymentu" ${ }^{31}$.

Co ciekawe, na pomoc przyszły jej osoby, których nieufność wobec szczepień przeciw COVID-19 motywowana była zgoła czym innym. W tym momencie warto przejść do teorii spiskowych na temat szczepionki, nad którą wciąż trwają prace i badania. Na własnej skórze przekonałam się, jak silny w swojej retoryce jest ruch antyszczepionkowy, gdy na początku maja wybrałam się na spacer do lasu. Spotkałam tam pogodnego mężczyznę w sile wieku, który w ciągu dziesięciu minut wyłożył mi przyczynę powstania SARS-CoV-2 i jego rozprzestrzenienia się po świecie oraz plan przejęcia kontroli nad ludźmi przez bliżej nieokreślone elity. Był on jednym z tych przedstawicieli ruchu antyszczepionkowego, którzy uwierzyli w teorię o charakterze spiskowym głoszącą, że pod pretekstem szczepienia przeciw COVID-19, organizowanego na globalną skalę, odbędzie się wszczepiane mikroczipów, mających umożliwić niejawnej grupie trzymającej władzę przejęcie całkowitej kontroli nad ludźmi.

\section{Wielkich zdarzeń wielka przyczyna}

W myśl prawa styczności, którym kieruje się myślenie magiczne, następstwo musi być podobne do przyczyny, gdyż jedno z drugim jest skorelowane: jedno $\mathrm{w}$ chodzi $\mathrm{z}$ drugim $\mathrm{w}$ kontakt. Takie zjawiska muszą być ontologicznie tożsame co najmniej pod tym względem, że właściwości następstwa muszą być tożsame $\mathrm{z}$ właściwościami przyczyny ${ }^{32}$. Jeśli zatem pandemia uzyskała wymiar globalny, bo objęła cały świat, jej powstanie również musiało mieć globalną przyczynę. Dlatego dla osób podatnych na teorie spiskowe nie do przyjęcia są wyjaśnienia naukowców, że przyczyną śmierci tak wielu osób, powodem kryzysu gospodarczego oraz zrujnowania ich osobistych planów na 2020 rok mógłby być błahy brak higieny na tzw. mokrym targu w Wuhan w Chinach. Skutki

31 Komentarz pod artykułem: R. CHABAsı́́ski: Koronawirus najwyraźniej niczego nie nauczył antyszczepionkowców. Wystarczyła wzmianka ministra zdrowia o szczepionce, by znów się uaktywnili. Bezprawnik, 19.04.2020. https://bezprawnik.pl/antyszczepion kowcy-koronawirus/ [data dostępu: 17.06.2020].

32 J.G. Frazer: Złota gałaź. Przeł. H. Krzeczkowski. Warszawa 1996, s. 38-81; M. Mauss: Socjologia i antropologia. Przeł. M. Król, K. Pomian, J. Szacki. Warszawa 1973, s. 4-5. 
pandemii są globalne, myślenie magiczne skłania więc do poszukiwania przyczyny o takim samym zasięgu. Skoro skorelowane ze sobą zjawiska powinny być do siebie podobne, przyczyna musi mieć taką samą wagę co skutek, stąd też przekonanie, że SARS-CoV-2 został wyprodukowany $\mathrm{w}$ chińskim laboratorium na zlecenie bliżej nieokreślonej grupy interesu. Brnąc nieco dalej w podobnym rozumowaniu można nawet przyjąć, że wirus ten w ogóle nie istnieje, a ten, kto stworzył dotyczące go fikcyjne informacje i globalnie je upowszechnił, próbuje w ten sposób przejąć kontrolę nad światem. W tym trybie kształtują się liczne teorie spiskowe, a część $\mathrm{z}$ nich wpisuje się $\mathrm{w}$ dyskurs antyszczepionkowy, jeśli w jego obrębie funkcjonują narracje, wedle których ogólna dostępność szczepionek w skali całego świata oraz globalne promowanie różnych programów szczepień jest częścią planu przejęcia kontroli nad ludzkością przez bliżej nieokreślone elity.

Jedną z teorii spiskowych, której korzenie sięgają niemal stu lat wstecz, a która najczęściej pojawia się w popularnych narracjach spiskowych wśród przeciwników szczepień, jest tak zwana teorią „nowego porządku świata" - łac. Novus Ordo Mundi, ang. New World Order (NWO). Trzonem wpisujących się w nią narracji jest przekonanie o istnieniu pewnej uprzywilejowanej grupy ludzi (nazywanej najczęściej elitą, światową finansjerą, często utożsamianej ze społecznością żydowską), której działania mają doprowadzić do powstania „nowego porządku świata”. Polegałby on na zniszczeniu suwerenności poszczególnych państw i wprowadzeniu autorytarnych rządów światowych oraz na depopulacji ludności na drodze wyeliminowania tych, którzy są najmniej pożądani. Zwolennicy tej teorii głoszą, że owymi niechcianymi jednostkami są tzw. zwykli ludzie. Wszystkie plany, o jakie oskarżana jest niesprecyzowana grupa dążąca rzekomo do przejęcia kontroli nad światem, docelowo mają uderzyć w tych, których jest najwięcej, a którzy przez rożne ograniczenia (intelektualne, finansowe, klasowe) nie mają bezpośredniego wpływu na decyzje podejmowane na wyższych szczeblach władzy w ramach instytucji o charakterze gospodarczym lub politycznym. Właśnie tam ma się znajdować pole działania spiskowców, którzy według teorii NWO należą do elit. Są nimi członkowie rządów państw oraz miliarderzy, tacy jak rodzina Rothschildów, Rockefellerów oraz Bill Gates ${ }^{33}$. Za dowód służy tu określenie „nowy porządek świata”, które było używane przez prezydentów dwóch największych mocarstw (George’a W. Busha i Michaiła Gorbaczowa) w kontekście zmian, jakie dokonały się na arenie międzynarodowej po rozpadzie ZSRR ${ }^{34}$.

33 Patrz np. O planach stworzenia rządu światowego. Wolne Media, 10.08.2020. https:// wolnemedia.net/o-planach-stworzenia-rzadu-swiatowego/ [data dostępu: 17.08.2020].

34 M. Fenster: Conspiracy theories. Secrecy and power in American culture. Minnesota 2008. 
Wydarzeniem, które pobudziło wyobraźnię antyszczepionkowców, była wypowiedź Gatesa w niemieckiej telewizji publicznej ARD z początku kwietnia 2020, kiedy wyznał, że liczy na to, że szczepionka przeciw COVID-19 będzie gotowa już za osiemnaście miesięcy ${ }^{35}$. Zwolennicy teorii spiskowych, w tym również część antyszczepionkowców, zadali sobie pytanie: dlaczego Gatesowi tak na tym zależy? Fakt, że fundacja Bill \& Melinda Gates od lat wspiera finansowo programy upowszechniania szczepień, został wykorzystany przeciwko założycielowi firmy Microsoft. Powstały dwie znaczące teorie spiskowe ${ }^{36}$ wyjaśniające, dlaczego jeden $\mathrm{z}$ najbogatszych ludzi na świecie postanowił wspierać i promować walkę z pandemią za pomocą szczepionki.

Zgodnie z pierwszą z teorii, Gates inwestuje w szczepionki przeciw COVID-19 i wymusza na decydentach różnych państw wprowadzenie obowiązku szczepień. Wynalezione szczepionki będą kupowane przez różne kraje i w ten sposób miliarder wzbogaci się jeszcze bardziej, stając się zarazem swoistym bohaterem swoich czasów. Według zwolenników tej teorii Gates i jego współpracownicy mają od dawna opracowany scenariusz, według którego wraz z podawaniem szczepionek media publiczne będą stopniowo wygaszać fatalistyczną narrację o pandemii, ludzie przestaną udawać, że są chorzy, i wszystko wróci do poprzedniego stanu. Jednakże są i tacy, którzy uważają, że firmie Microsoft dalsze mnożenie zysków nie jest potrzebne, co skłania ich do podejrzeń, że sytuacja jest znacznie poważniejsza. Według drugiej teorii spiskowej dotyczącej Gatesa, w rzekomo wywołanej przez niego pandemii nie chodzi o pieniądze, ale o przejęcie kontroli nad światem poprzez monitorowanie zdrowia i sposobu funkcjonowania zaszczepionych osób. Koncepcja ta zawiera zatem bezpośrednie odwołania do NWO i nawet jeśli z perspektywy nauki oraz łatwo sprawdzalnych faktów jest mniej prawdopodobna niż pierwsza, cieszy się rosnącą popularnością.

Wyobraźnia, w którą wpisują się teorie o spiskach i która pozwala się zidentyfikować wśród użytkowników internetu, podsycana jest przez różnego rodzaju niesprawdzalne informacje, zamieszczane w serwisach takich jak Facebook i Twitter przez boty społecznościowe ${ }^{37}$. Trudno je zweryfikować, a w przypadku wielu z nich po jakimś czasie okazuje się, że są fałszywe. Rozmawiając dziś z własnymi krewnymi, przyjaciółmi lub

35 U. Lesman: Bill Gates stworzył koronawirusa. Wywiad ma być dowodem. Cyfrowa. rp.pl, 18.04.2020. https://cyfrowa.rp.pl/biznes/46130-bill-gates-stworzyl-koronawirusawywiad-ma-byc-dowodem [data dostępu: 20.05.2020].

$36 \mathrm{Na}$ podstawie analizy częstotliwości występowania tych narracji w serwisie Wolne Media.

37 Bot społecznościowy to system informatyczny, który imituje aktywność internautów w mediach społecznościowych; może on konstruować fikcyjne profile użytkowników, zawierające fałszywe dane (na przykład życiorys), i udostępniać na takich profilach określone informacje. 
przypadkowo spotkanymi ludźmi nie tak trudno natrafić na pogląd, że SARS-CoV-2 nie istnieje, a rzekoma pandemia COVID-19 została wymyślona przez ludzi takich jak Bill Gates i Anthony Fauci, światowej sławy amerykański immunolog, doradca prezydentów Stanów Zjednoczonych Ameryki, któremu amerykanie zawdzięczają rozpoczęcie walki z wirusem HIV. Gates, jako filantrop i osoba publiczna, oraz Fauci od lat łączą swoje siły $\mathrm{w}$ walce $\mathrm{z}$ różnymi chorobami pochodzenia wirusowego, co w percepcji zwolenników teorii spiskowych samo w sobie jest zastanawiające i niebezpieczne.

Opierając się na informacji, że w szczepionkach miałyby znajdować się mikroczipy, dzięki którym „możnowładcy tego świata” (Gates i jemu podobni) uzyskają kontrolę nad stanem zdrowia wszystkich zaszczepionych, a nawet nad ich umysłami, zwolennicy teorii spiskowych czują potrzebę przeciwdziałania podobnemu zamachowi na wolność. "Alternatywne" serwisy informacyjne zasypują słuchaczy i czytelników ostrzeżeniami, że Gates chce uczynić z ludzi niewolników, którymi będzie mógł dowolnie sterować. Jeśli zaś chodzi o Fauciego, ma nim kierować nie tylko wizja zysków finansowych. Fauci rzekomo realizuje swój plan depopulacji ludzkości ${ }^{38}$. O przeludnieniu dowiadujemy się nie tylko w szkole, ale i z telewizji, w której co jakiś czas podawane są informacje o kolejnym prezydencie, premierze lub milionerze zwracającym uwage na katastrofalne skutki ekologiczne przeludnienia planety. Inne źródła mogą z kolei zaprzeczać podobnym tezom ${ }^{39}$. Słowem, Gates i Fauci pragną wyeliminować najmniej pożądane i użyteczne (z ich punktu widzenia) jednostki, co rodzi obawy, a jednocześnie łagodzi je, skoro knowania spiskowców zostały zdemaskowane. Teoria spiskowa ma to do siebie, że - poniekąd paradoksalnie - niweluje poczucie zagrożenia, którego sama jest źródłem.

Powtórzmy, teorie spiskowe dotyczące pandemii COVID-19 zbudowane są na przekonaniu, że dyskutowane na całym świecie zjawisko nie może być wynikiem trywialnego zdarzenia. Jak skonstatowano, błąd poznawczy polega tu na przewidzeniu dla znaczącego skutku równie znaczącej przyczyny ${ }^{40}$. Istotna jest także ewentualna trudność pogodzenia się z przypuszczeniem, że katastrofa dotykająca wielkiej liczby ludzi, czasem oznaczająca też nasze własne nieszczęście, mogłaby być spowodowana błahostką lub - co gorsza - bezmyślnością. Pandemia jest wyzwaniem obecnych czasów i tragedią wielu ludzi. Od samego początku

38 Patrz np. Bill Gates i dr Anthony Fauci inżynierami projektu depopulacji. Wolne Media, 16.04.2020. https://wolnemedia.net/bill-gates-i-dr-anthony-fauci-inzynieramiprojektu-depopulacji/ [data dostępu: 29.05.2020].

39 Patrz np. Przeludnienie to mit. Wolne Media, 14.08.2020. https://wolnemedia. net/przeludnienie-to-mit/ [data dostępu: 6.06.2020].

40 M. Grzesiak-Feldman: Psychologia myślenia spiskowego. Warszawa 2016, s. 53. 
wymaga od społeczeństwa wyjścia ze strefy komfortu, porzucenia dotychczasowego trybu życia i rezygnacji z wielu przyzwyczajeń. Kazano zostać w domu i zachować dystans społeczny, co miało pozwolić ocalić siebie i swoich bliskich. Dopóki sytuacja trwała kilka dni, Polacy stawali na wysokości zadania. Dziśs, kiedy mijają kolejne miesiące pandemii, niektórzy wątpią w jej realność zastanawiają się, czy konwój trumien wywożonych z Bergamo nie był mistyfikacją, czy w trumnach nie znajdywały się przypadkiem ciała uchodźców z Bliskiego Wschodu, którzy utonęli w wodach Morza Śródziemnego ${ }^{41}$.

Bez względu na tego typu wątpliwości pandemia spowodowała zapaść w gospodarce, wzrost bezrobocia, uczniowie nie mogli chodzić do szkół, opóźnił się termin zdawania egzaminów dojrzałości, zamknięto granice, spadła wartość niektórych walut i nastąpił zauważalny wzrost cen. Z konsekwencjami zaistniałej sytuacji przyjdzie się borykać przez kilka lat. W świetle wymienionych problemów trudno jest zaakceptować fakt, że wszystko to zostało spowodowane brakiem odpowiedniej higieny na targu w Chinach oraz nieadekwatną do stopnia zagrożenia reakcją władz tego kraju. Podobne wyjaśnienia nie dają poczucia bezpieczeństwa ani stabilności, a jest ono niezbędne dla sprawnego i bezkonfliktowego funkcjonowania $\mathrm{w}$ świecie zarówno zwolennikom teorii spiskowych, jak i tym, którzy z różnych przyczyn opierają się „myśleniu na skróty”. U jego podstaw stoją błędy poznawcze, których efektem jest to, co chciałabym nazwać nieracjonalnym odbiorem rzeczywistości. Analizowane tu teorie spiskowe opierają się na myśleniu magicznym, wedle którego przyczyna musi być podobna do powodowanego przez nią skutku (inaczej: cechy przyczyny dają się wyprowadzić z cech jej skutku), skoro jedno jest $\mathrm{z}$ drugim jest skorelowane i pod tym względem wchodzi w styczność.

Podobne założenia sprawdzają się znacznie lepiej niż założenia dyskursu naukowego, według których rzeczywistość jest złożona, a docieranie do niej wymaga jasno określonych metodyk. W ramach tego dyskursu przyjmuje się również, że płynące z badań naukowych wnioski zawsze są niepewne, opierają się na rachunku prawdopodobieństwa i mogą uchodzić za prawdziwe, dopóty inne, formalnie poprawne dociekania nie doprowadzą do ich podważenia. Myślenie magiczne nie potrzebuje Popperowskiej zasady falsyfikalności, nie dopuszcza możliwości błędów popełnianych w laboratoriach i nie akceptuje żadnych przestojów na drodze do uzyskania remedium na jakąkolwiek dolegliwość czy inne przeciwieństwo losu. W podobnym myśleniu warunkiem skuteczności

41 Należy zaznaczyć, że powstanie takiej teorii świadczy o niehumanitarnym stosunku jej twórców czy zwolenników do uchodźców z Bliskiego Wschodu i Afryki Północnej; informacje o ich ciałach wywożonych z Bergamo miały charakter prześmiewczy i bagatelizujący, jak gdyby śmierć muzułmanina lub Araba była mniej istotna niż śmierć obywatela Włoch z powodu COVID-19. 
podejmowanych działań nie jest wysiłek poznawczy. W pełni wystarczą tu odwołania do wiedzy codziennej, potocznej, opartej na ogólnodostępnym doświadczeniu ${ }^{42}$. Dopóki pandemia nie wkroczy w naszą codzienność, a więc dopóki nic nam ani nikomu z naszych bliskich nie dolega, łatwo o przekonanie, że tak naprawdę jest ona wymysłem. Trzeba pamiętać, że w niektórych regionach Polski do jesieni 2020 roku trudno było spotkać osobę, która znała kogoś, kto zachorował na COVID-19. Wiedza potoczna dostarcza człowiekowi czegoś, czego nie daje mu nauka. Dostarcza doraźnych przepisów na wszystko, koi lęki i zapewnia poczucie bezpieczeństwa ontologicznego ${ }^{43}$.

Na poziomie potoczności znaczenie ma informacja, która potwierdza własne założenia poznawcze odbiorcy, a nie wiarygodność jej nadawcy. Gdyby sięgnąc do przykładu, jeden z moich informatorów przyznał, że dla niego i jego znajomych liczy się sama informacja, a nie źródło, $\mathrm{z}$ jakiego ona pochodzi ${ }^{44}$. Podobnie rzecz ma się $\mathrm{z}$ autorytetem samego zawodu naukowca, który charakteryzuje się „wnikliwością w rozróżnianiu rzeczy na pozór jednakowych, zdolnością kojarzenia rzeczy na pozór ze sobą nie związanych oraz krytycyzmem w rozpoznawaniu prawd i fałszów mających pozory prawd" ${ }^{\prime 4}$. Wnikliwość, żmudna analiza, falsyfikowalność i weryfikowalność wniosków nie są tym, na czym zależy człowiekowi w codziennym życiu. Codzienność wymaga natychmiastowej skuteczności, szybkiego i bezpośredniego dostępu do pożądanych informacji. Na tej niwie myślenie typu Popperowskiego musi przegrywać $\mathrm{z}$ myśleniem magicznym.

Jeśli pozwolić sobie na krótką dygresję zaczerpniętą z popkultury, można wskazać, że relacjonowane tu ścieranie się dwóch zasadniczych sposobów porządkowania świata dosadnie oddaje scena $\mathrm{z}$ kultowego serialu telewizyjnego lat dziewięćdziesiątych pod tytułem Przystanek Alaska. W jednym z odcinków, którego fabuła skupia się na wizycie cyrkowców w małym (fikcyjnym) miasteczku Cicely na Alasce, można wysłuchać dialogu Chrisa, który jest miejscowym intelektualistą, z cyrkowcem, który wcześniej był wykładowcą fizyki. Mężczyźni rozmawiają o fizyce kwantowej, kwarkach i cząstkach neutrino. W trakcie rozmowy były wykładowca wyznaje: „Fizyka zawsze budziła mój niepokój. Na subatomowym poziomie wszystko jest dziwaczne. W magii zyskałem trochę kontroli”46.

42 P.L. Berger, T. Luckmann: Społeczne tworzenie rzeczywistości. Przeł. J. Niżnik. Warszawa 2019, s. 51-67.

43 A. Giddens: Konsekwencje nowoczesności..., s. 65-66.

$44 \mathrm{Na}$ podstawie rozmowy $\mathrm{z}$ przedstawicielem ruchu antyszczepionkowego 9 czerwca 2020 roku.

45 M. Mazur: Historia naturalna polskiego naukowca. Warszawa 1979, s. 41.

46 Przystanek Alaska [serial telewizyjny]. Reż. M. Katleman. 1990-1995. Seria 3, odcinek 9. 


\section{Jak troszczyć się o życie?}

Thomas Hobbes w Lewiatanie sprowadza przyczynę wszystkich ludzkich zachowań do lęku i opisuje człowieka jako „projekt” pomyślany „od dołu", jako kogoś, kto potrzebuje, aby nim kierowano lub przynajmniej dano mu jasno określone zasady, w jaki sposób ma postępować ${ }^{47}$. Brak konkretności i rozmycie informacji dotyczących pandemii COVID-19 przyczyniły się do określonego radykalizmu społecznego, który domaga się klarownej, łatwo przystępnej wiedzy o wszystkim i nie chce wstrzymywać się zbędnymi rozważaniami natury epistemologicznej ${ }^{48}$. Lęk przed nieznaną do tej pory chorobą, niepokój związany z zapaścią gospodarczą oraz poczucie niepewności wynikające $\mathrm{z}$ naporu szybko zmieniających się sprzecznych informacji ( $w$ tym tych fałszywych) wymagały od dyspozytorów dyskursu publicznego oraz potocznego wynalezienia narracji o charakterze spiskowym. Skoro nauka nie daje poczucia kontroli anico za tym idzie - poczucia bezpieczeństwa, naturalnym z ewolucyjnego punktu widzenia mechanizmem jest odwołanie się do czegoś innego, co zapewni poczucie stabilności. Nie podparte żadnymi dowodami narracje spiskowe zyskują zatem charakter ewolucyjnie uzasadnionej reakcji na sytuację stresową, ponieważ dają swemu zwolennikowi poczucie orientacji w świecie i kontroli nad zdarzeniami, które w okresie pandemii determinują sposób życia.

Należy zaznaczyć, że przeciwnicy szczepień konstruują doświadczaną przez siebie rzeczywistość za pomocą niekonkretnych i często sprzecznych poglądów, co jest charakterystyczne dla wiedzy potocznej. Zwolennicy teorii spiskowych potrafią oswoić - czyli zaadaptować na korzyść własnych poglądów - również zdarzenia, od których skądinąd można by oczekiwać, że zachwieją spiskowym światopoglądem. Sprawdzalne fakty wskazujące na zasadność stosowania szczepionek w celu przeciwdziałania pandemii zawsze można zinterpretować na rzecz lansowanego obrazu świata: jeśli wirus ustępuje tam, gdzie prowadzi się szczepienia, dowodzi to nie tyle skuteczności szczepień, ile tego, że nigdy nie istniał. Świadczy to, w odniesieniu do uwarunkowań historyczno-kulturowych, o kondycji człowieka ponowoczesnego, zanurzonego $\mathrm{w}$ niestabilnym świecie informacji napływających z różnych źródeł. Jeśliby zaś odnieść się do uwarunkowań biologicznych, można stwierdzić, że za potocznymi strategiami przeciwdziałania lękom i za walką o poczucie bezpieczeństwa stoją mechanizmy ewolucyjne. Są one odpowiedzialne za błędy poznawcze, które dają nam pozorną kontrolę nad naszym życiem. Dyspozytorzy

47 T. Новвеs: Lewiatan, czyli materia, forma $i$ władza państwa kościelnego i świeckiego. Przeł. C. Znamierowski. Warszawa 2005.

48 H. Plessner: Granice wspólnoty. Krytyka radykalizmu społecznego. Przeł. J. MeRECKI. Warszawa 2008. 
dyskursu spiskowego jawią się jako nieufni wobec władzy, systemu, powszechnie uznawanych autorytetów oraz nauki, ale pewne jest, że ufają oni sobie i to właśnie w sobie będą szukać stabilności, która w świecie nowych mediów i postprawdy zdaje się być niemal niedostępna. Teorie spiskowe postrzegane są przez swych zwolenników jako źródło wiedzy o tym, jak funkcjonować w świecie, by nie dać się oszukać i spacyfikować przez ukrytego wroga. Pod tym względem oferują łatwo dostępną receptę na przeżycie w czasach niepewności.

\section{Bibliografia}

Badaja, jak przekonać ludzi do szczepień na COVID-19. Wolne Media, 4.08.2020. https://wolnemedia.net/badaja-jak-przekonac-ludzi-do-szczepien-na-co vid-19/ [data dostępu: 17.08.2020].

Baudrillard J.: Wojny w Zatoce nie byto. Przeł. A. Królak. Warszawa 2006.

Berger P.L., Luckmann T.: Spoleczne tworzenie rzeczywistości. Przeł. J. NiżniK. Warszawa 2010.

Bill Gates $i$ dr Anthony Fauci inżynierami projektu depopulacji. Wolne Media, 16.04.2020. https://wolnemedia.net/bill-gates-i-dr-anthony-fauci-inzy nierami-projektu-depopulacji/ [data dostępu: 29.05.2020].

Chabasiński R.: Koronawirus najwyraźniej niczego nie nauczył antyszczepionkowców. Wystarczyła wzmianka ministra zdrowia o szczepionce, by znów się uaktywnili. Bezprawnik, 19.04.2020. https://bezprawnik.pl/antyszczepion kowcy-koronawirus/ [data dostępu: 17.06.2020].

Czech F.: Spiskowe narracje i metanarracje. Kraków 2015.

Czy istnieja jakieś bezpieczne szczepionki? Wolne Media, 6.01.2020. https:// wolnemedia.net/czy-istnieja-jakies-bezpieczne-szczepionki/ [data dostępu: 15.05.2020].

Demczuк A.: Fenomen ruchu antyszczepionkowego w cyberprzestrzeni..., czyli fake news i postprawda na uslugach hipotezy Andrew Wakefielda, „Annales Universitatis Paedagogicae Cracoviensis. Studia de Cultura" 2018, [t.] 10 (4), s. $92-113$.

DoŁowy K.: Wbrew bogom, czyli od magii i religii do metody naukowej... i z powrotem. Warszawa 2020.

FAIRCLOUGH N.L.: Language and power. London 1989.

Fairclough N.L., Wodak R.: Critical discourse analysis. W: Discourse studies. A multidisciplinary introduction. Vol. 2: Discourse as social interaction. Ed. T.A. VAN DIJK. 1997, s. 258-284.

Fenster M.: Conspiracy theories. Secrecy and power in American culture. Minnesota 2008.

Frazer J.G.: Złota gałaź. Przeł. H. Krzeczkowski. Warszawa 1996.

Giddens A.: Konsekwencje nowoczesności. Przeł. Е. Кцекот. Kraków 2000.

Grzesiak-Feldman M.: Psychologia myślenia spiskowego. Warszawa 2016.

Hоввеs T.: Lewiatan, czyli materia, forma i władza państwa kościelnego i świeckiego. Przeł. C. Znamierowski. Warszawa 2005. 
Kajfosz J.: Dyskurs analityczny $i$ syntetyczny, czyli myślenie magiczne $w$ perspektywie antropologii kognitywnej. „Artes Humanae” 2016, vol. 1, s. 27-40.

KAJFOSz J.: Neoliberalism, the rise of new media folklore and the emergence of new nationalisms. „Berlin Journal of Critical Theory” 2019, vol. 3, no. 2, s. $27-47$.

Kowalski, P.: Theatrum świata wszystkiego i poćciwy gospodarz. O wizji świata pewnego siedemnastowiecznego pisarza ziemiańskiego. Kraków 2000.

Lesman U.: Bill Gates stworzył koronawirusa. Wywiad ma być dowodem. Cyfrowa.rp.pl, 18.04.2020. https://cyfrowa.rp.pl/biznes/46130-bill-gates-stworzylkoronawirusa-wywiad-ma-byc-dowodem [data dostępu: 20.05.2020].

LÉvy-BruHL L.: Czynności umysłowe $w$ społecznościach pierwotnych. [Przeł. B. Szwarcman-Czarnota]. Warszawa 1992.

Malewska-SzaŁygin A.: Tradycja stosowania pojęcia dyskurs $i$ jego przydatność w antropologii współczesności. „Etnografia Polska” 2004, t. 48, z. 1-2, s. 81-97.

Marchewka A.K., Majewska A., MŁynarczyk G.: Działalność ruchu antyszczepionkowego, rola środków masowego komunikowania oraz wpływ pogladów religijnych na postawę wobec szczepień ochronnych. „Postępy Mikrobiologii" 2015 , t. 54, z. 2, s. 95-103.

Mauss M.: Socjologia i antropologia. Przeł. M. KróL, K. Pomian, J. Szacki. Warszawa 1973.

Mazur M.: Historia naturalna polskiego naukowca. Warszawa 1979.

Naukowcy ONZ przyznali, że szczepionki zabijają ludzi. Wolne Media, 12.01.2020. https://wolnemedia.net/naukowcy-onz-przyznali-ze-szczepionki-zabijajaludzi/ [data dostępu: 29.08.2020].

O nas. Wolne Media. https://wolnemedia.net/o-nas/ [data dostępu: 30.04.2020].

O planach stworzenia rządu światowego. Wolne Media, 10.08.2020. https:// wolnemedia.net/o-planach-stworzenia-rzadu-swiatowego/ [data dostępu: 17.08.2020].

Państwo namawia na szczepionki przeciw grypie. Wolne Media, 26.09.2018. https://wolnemedia.net/panstwo-namawia-na-szczepionki-przeciw-grypie/ [data dostępu: 17.08.2020].

Plessner H.: Granice wspólnoty. Krytyka radykalizmu społecznego. Przeł. J. MERECKI. Warszawa 2008.

Przeludnienie to mit. Wolne Media, 14.08.2020. https://wolnemedia.net/przeludnienie-to-mit/ [data dostępu: 6.06.2020].

Przymusowe szczepionki od Billa Gatesa [materiał wideo]. Wolne Media, 25.05.2020. https://wolnemedia.net/przymusowe-szczepionki-od-billa-gatesa/ [data dostępu: 17.08.2020].

Przystanek Alaska [serial telewizyjny]. Reż. M. Katleman. 1990-1995. Seria 3, odcinek 9.

Rовотүскі C.: Społeczność a współczesny regionalizm i tożsamość lokalna. „Zeszyty Etnologii Wrocławskiej” 2012, [nr] 2 (17), s. 19-41.

Szczepionki albo życie. Wolne Media, 18.08.2020. https://wolnemedia.net/szcze pionki-albo-zycie/ [data dostępu: 28.08.2020].

ToKARsKa-BAKIR J.: Obraz osobliwy. Hermeneutyczna analiza źródet etnograficznych. Kraków 2000. 
Trwa medialna nagonka, aby wstrzykiwać szczepionki przeciwko MMR. Wolne Media, 6.11.2020. https://wolnemedia.net/trwa-medialna-nagonka-abywstrzykiwac-szczepionki-mmr/ [data dostępu: 17.08.2020].

WAsZaK M.: Postprawda i fake news czy weryfikacja treści i źródet informacji? „Refleksje” 2017, nr 2 (16), s. 173-188.

Wiara $w$ szczepionki to absurd. Chlorochina rokuje nadzieje. Wolne Media, 15.05.2020. https://wolnemedia.net/wiara-w-szczepionki-to-absurdchlorochina-rokuje-nadzieje/ [data dostępu: 28.08.2020].

Wolne Media. https://wolnemedia.net/ [data dostępu: 30.04.2020, 15.05.2020]. wRealu24. https://www.wrealu24.pl [data dostępu: 15.05.2020].

Ewa Kozik, antropolożka kulturowa, religioznawczyni i badaczka terenowa. Od 2019 roku doktorantka w Szkole Doktorskiej w Uniwersytecie Śląskim. Zajmuje się analizą mitów współczesnych z perspektywy socjologii wiedzy i antropologii filozoficznej. Interesuje się problematyką percepcji kultur bliskowschodnich oraz kultur Azji Południowo-Wschodniej. 